Y/DV-1614

\title{
Investigation of Cracked Lithium Hydride Reactor Vessels
}

E. L. Bird and T. M. Mustaleski, Jr.

Issue Date: July 2, 1999 


\section{DISCLAIMER}

This report was prepared as an account of work sponsored by an agency of the United States Government. Neither the United States Government nor any agency thereof, nor any of their employees, makes any warranty, express or implied, or assumes any legal liability or responsibility for the accuracy, completeness, or usefulness of any information, apparatus, product, or process disclosed, or represents that its use would not infringe privately owned rights. Reference herein to any specific commercial product, process, or service by trade name, trademark, manufacturer, or otherwise, does not necessarily constitute or imply its endorsement, recommendation, or favoring by the United States Government or any agency thereof. The views and opinions of authors expressed herein do not necessarily state or reflect those of the United States Government or any agency thereof. 


\title{
INVESTIGATION OF CRACKED LITHIUM HYDRIDE REACTOR VESSELS
}

\author{
E. L. Bird and T. M. Mustaleski, Jr.
}

Materials Engineering Department Development Division

Issue Date: July 2, 1999

\author{
Prepared by the \\ Oak Ridge Y-12 Plant \\ Oak Ridge, Tennessee 37831-8169 \\ managed by \\ LOCKHEED MARTIN ENERGY SYSTEMS, INC. \\ for the \\ U.S. DEPARTMENT OF ENERGY \\ under contract DE-AC05-84OR21400
}





\section{CONTENTS}

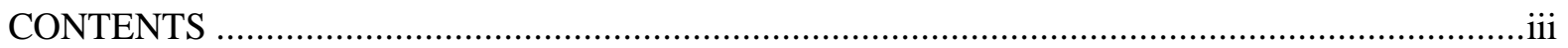

LIST OF FIGURES

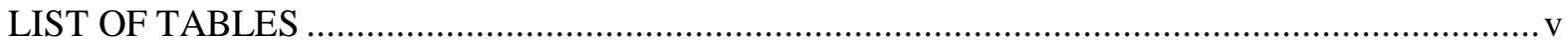

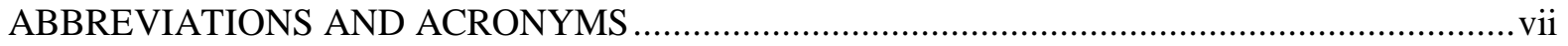

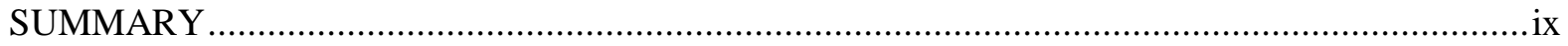

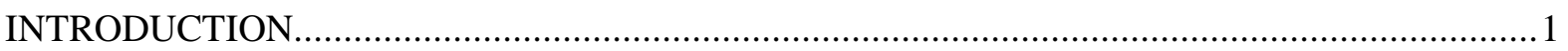

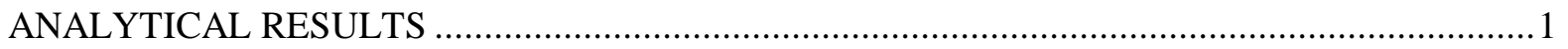

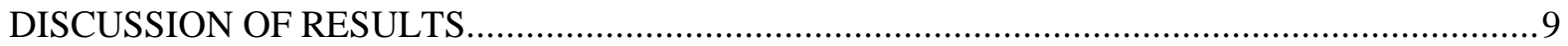

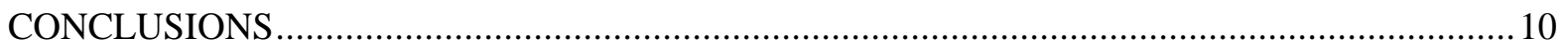

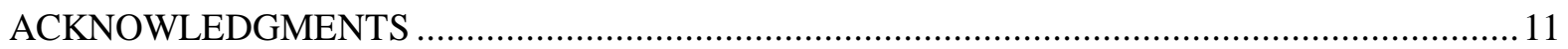

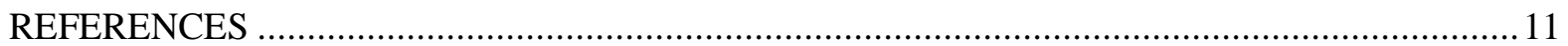




\section{LIST OF FIGURES}

$\underline{\text { Figure }}$

$\underline{\text { Page }}$

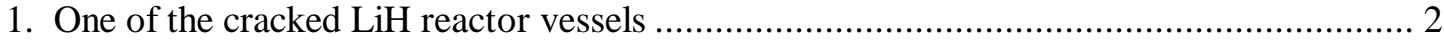

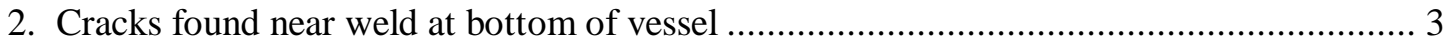

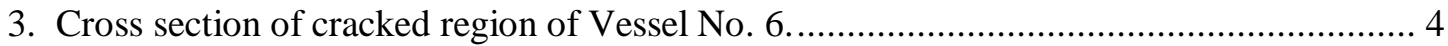

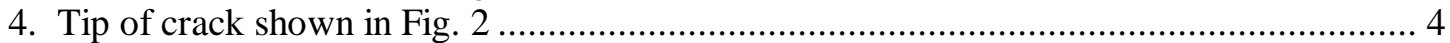

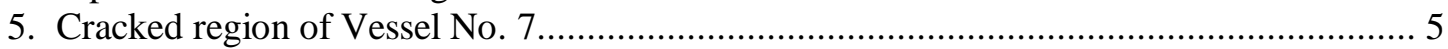

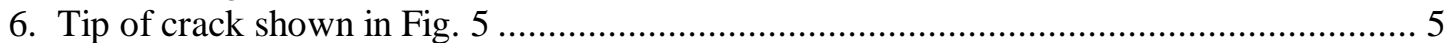

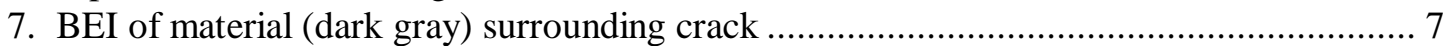

8. EDX analysis of material in crack: $\mathrm{Ni}, \mathrm{Fe}$, and CR ...................................................... 8

9. Section near the crack showing precipitates rich in chromium-carbon in the Type 309S

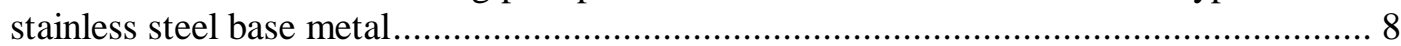

10. Welded region of Vessel No. 170 is crack-free and shows very little evidence of sensitization. 10

\section{LIST OF TABLES}

Table

$\underline{\text { Page }}$

1. History of vessels and results of visual inspections performed February 2-3, 1999.......... 3

2. Chemical requirements and results (wt \%) of vessel materials 6 


\section{ABBREVIATIONS AND ACRONYMS}

$\begin{array}{ll}\text { ASME } & \text { American Society of Mechanical Engineers } \\ \text { ASTM } & \text { American Society for Testing and Materials } \\ \text { AVS } & \text { Advanced Vacuum Systems } \\ \text { B\&PV } & \text { boiler and pressure vessel } \\ \text { BEI } & \text { backscattered electron image } \\ \text { C } & \text { carbon } \\ { }^{\circ} \mathrm{C} & \text { Celsius } \\ \text { Cl } & \text { chlorine } \\ \text { Co } & \text { cobalt } \\ \text { Cr } & \text { chromium } \\ \text { CTE } & \text { coefficient of thermal expansion } \\ \text { EDX } & \text { energy dispersive X-ray } \\ \text { F } & \text { fluorine } \\ { }^{\circ} \mathrm{F} & \text { Fahrenheit } \\ \text { Fe } & \text { iron } \\ \text { LiH } & \text { lithium hydride } \\ \text { Mn } & \text { manganese } \\ \mathrm{N} & \text { nitrogen } \\ \text { Ni } & \text { nickel } \\ \mathrm{O} & \text { oxygen } \\ \text { psi } & \text { pounds per square inch } \\ \text { S } & \text { sulfur } \\ \text { SEM } & \text { scanning electron microscope }\end{array}$




\section{SUMMARY}

Visual examination of lithium hydride reactor vessels revealed cracks that were adjacent to welds, most of which were circumferentially located in the bottom portion of the vessels. Sections were cut from the vessels containing these cracks and examined by use of the metallograph, scanning electron microscope, and microprobe to determine the cause of cracking. Most of the cracks originated on the outer surface just outside the weld fusion line in the base material and propagated along grain boundaries. Crack depths of those examined sections ranged from $\sim 300$ to $500 \mu \mathrm{m}$. Other cracks were reported to have reached a maximum depth of $1 / 8$ in. The primary cause of cracking was the creation of high tensile stresses associated with the differences in the coefficients of thermal expansion between the filler metal and the base metal during operation of the vessel in a thermally cyclic environment. This failure mechanism could be described as creep-type fatigue, whereby crack propagation may have been aided by the presence of brittle chromium carbides along the grain boundaries, which indicates a slightly sensitized microstructure. 


\section{INTRODUCTION}

Hydride reactor vessels are used to produce lithium hydride $(\mathrm{LiH})$ in an exothermic reaction process. Construction of the particular vessels in question occurred in the early '90s through a contract with Advanced Vacuum Systems (AVS). After the factory acceptance test, AVS found a crack in the welded region of one of the Type 309S stainless steel vessels. ${ }^{1}$ To repair the cracked vessel, all of the original stainless steel weld metal was machined out and rewelded with Inconel 617 filler wire from the outside. The weld metal was also buttered on the inside with ER-Type 309LT stainless steel wire. Subsequent thermal cycling and radiography of the repaired vessel showed no cracks, so the other vessels were repaired in the same manner.

The vessels in question were in operation for some time; recently, however, numerous cracks were found during a visual inspection. Figure 1 shows one of the cracked vessels. Table 1 provides a history summary of the operating life of these vessels and inspection results. A typical operating cycle consists of ramping up slowly to $\sim 700^{\circ} \mathrm{C}\left(1300^{\circ} \mathrm{F}\right)$, holding for several hours, and cooling by forced air. Most of the cracks were located along the circumferential welds at the bottom of the vessels. A few sections containing cracks next to the circumferential welds, similar to those shown in Fig. 2, were cut from two of the vessel walls and given to Development Division personnel at the Oak Ridge Y-12 Plant to perform failure analysis.

\section{ANALYTICAL RESULTS}

Sections of Vessel Nos. 6 and 7 were prepared for metallographic examination to determine the extent of cracking and to examine the integrity of the weld and shell microstructure. Cross sections of the cracked regions were mounted, polished, and etched with a 50\% nitric acid-50\% water mixture. The scanning electron microscope (SEM) and backscattered electron imaging were also used for examining the microstructure. The energy dispersive X-ray (EDX) was used to identify the metallic elements, whereas the electron microprobe was used to identify the lighter elements.

Figure 3 shows the crack in Vessel No. 6 . The crack depth shown in Fig. 3 is $\sim 300 \mu \mathrm{m}$ and appears to be propagating intergranularly along the grain boundaries. The microstructure appears to be slightly sensitized, and Fig. 4 shows some evidence of large precipitates in the grain boundaries. Several specimens from Vessel No. 7 were prepared in the same manner for metallographic examination. Fig. 5 shows one of the cracked regions. The largest of these cracks is $\sim 500 \mu \mathrm{m}$, and some evidence of sensitization exists, noted by the string of grain boundary precipitates as shown in Fig. 6. A crack $\sim 1 / 8$ in. long was discovered in the base plate. Sections were also taken from the weld and base material to verify the filler metal and base metal. That analysis appears in Table 2, which shows a partially diluted material that indicates that the filler metal is a nickel-based alloy similar to Inconel 617 and a substrate material that is similar to Type 309S stainless steel. During the course of the investigation, a short-term plan was developed to use portions of the "older" vessels manufactured by the Nooter Corporation of a different design, so that operations would not have to be shut down for the procurement of new vessels. Chemical analyses of those vessels, which were obtained before acceptance for repair, are also reported in Table 2. 


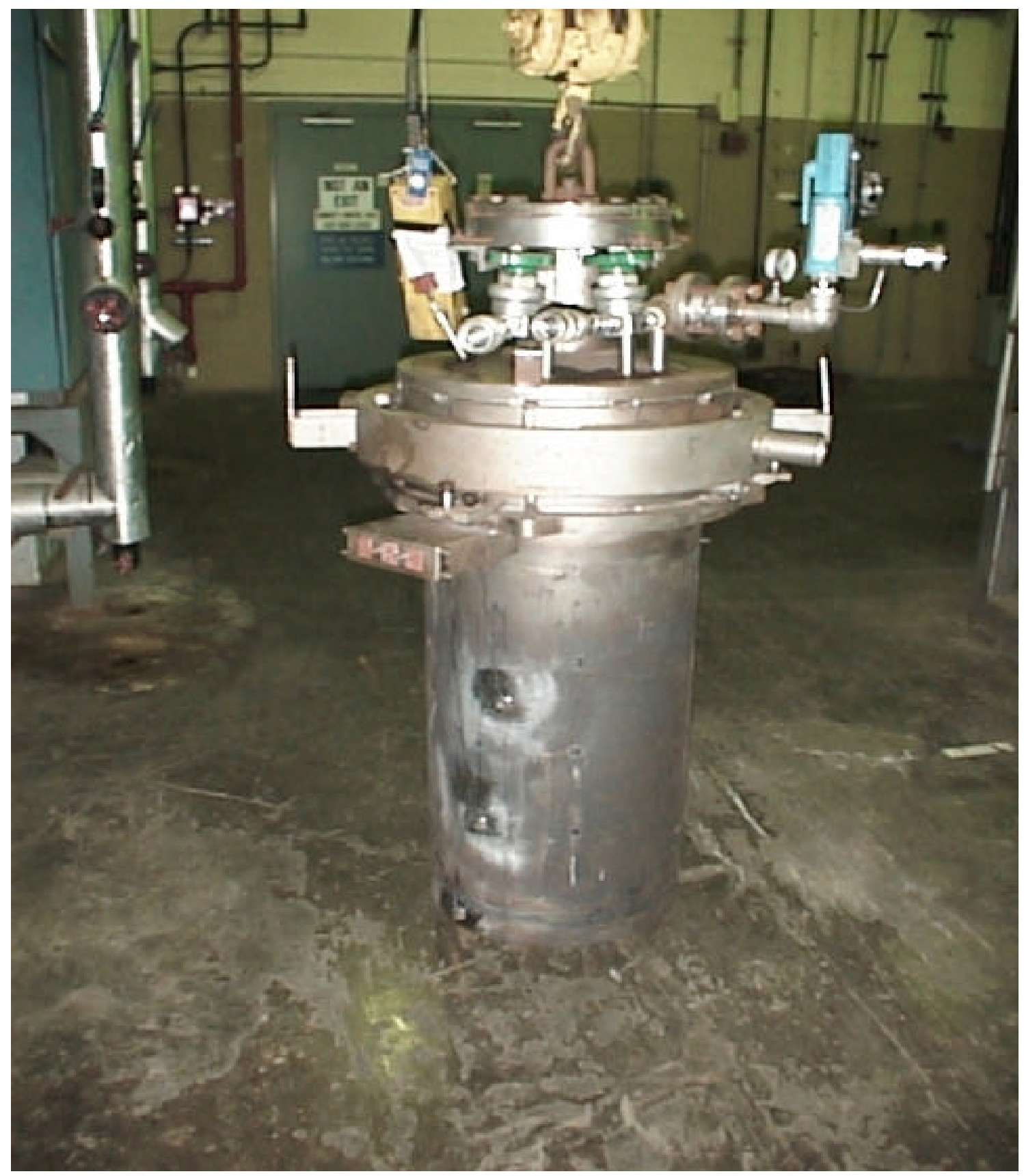

Fig. 1. One of the cracked $\mathrm{LiH}$ reactor vessels. 
Table 1. History of vessels and results of visual inspections performed February 2-3, 1999

\begin{tabular}{|c|c|c|l|l|}
\hline Vessel No. & $\begin{array}{c}\text { Number of } \\
\text { thermal }_{\text {cycles }^{\boldsymbol{a}}}\end{array}$ & $\begin{array}{c}\text { Estimated } \\
\mathbf{h} \mathbf{> 4 2 5}^{\mathbf{C}} \mathbf{C}\end{array}$ & \multicolumn{1}{|c|}{ Inspection results } & Results \\
\hline 1 & 44 & 821 & Four intermittent cracks <2 in. long & Rejected \\
\hline 2 & 33 & 612 & One crack $~ 4$ in. long on bottom outside weld & Rejected \\
\hline 3 & 49 & 916 & One continuous crack on bottom weld & Rejected \\
\hline 4 & 41 & 436 & One crack on bottom outside weld & Rejected \\
\hline 5 & 24 & 433 & Five crack-like areas on bottom outside weld & Rejected \\
\hline 6 & 44 & 501 & Six cracks on bottom outside weld & Rejected \\
\hline 7 & 45 & 752 & $\begin{array}{l}\text { Numerous linear cracks at edge of weld on } \\
\text { bottom outside weld }\end{array}$ & Rejected \\
\hline
\end{tabular}

${ }^{a}$ Includes experimental and operational runs.

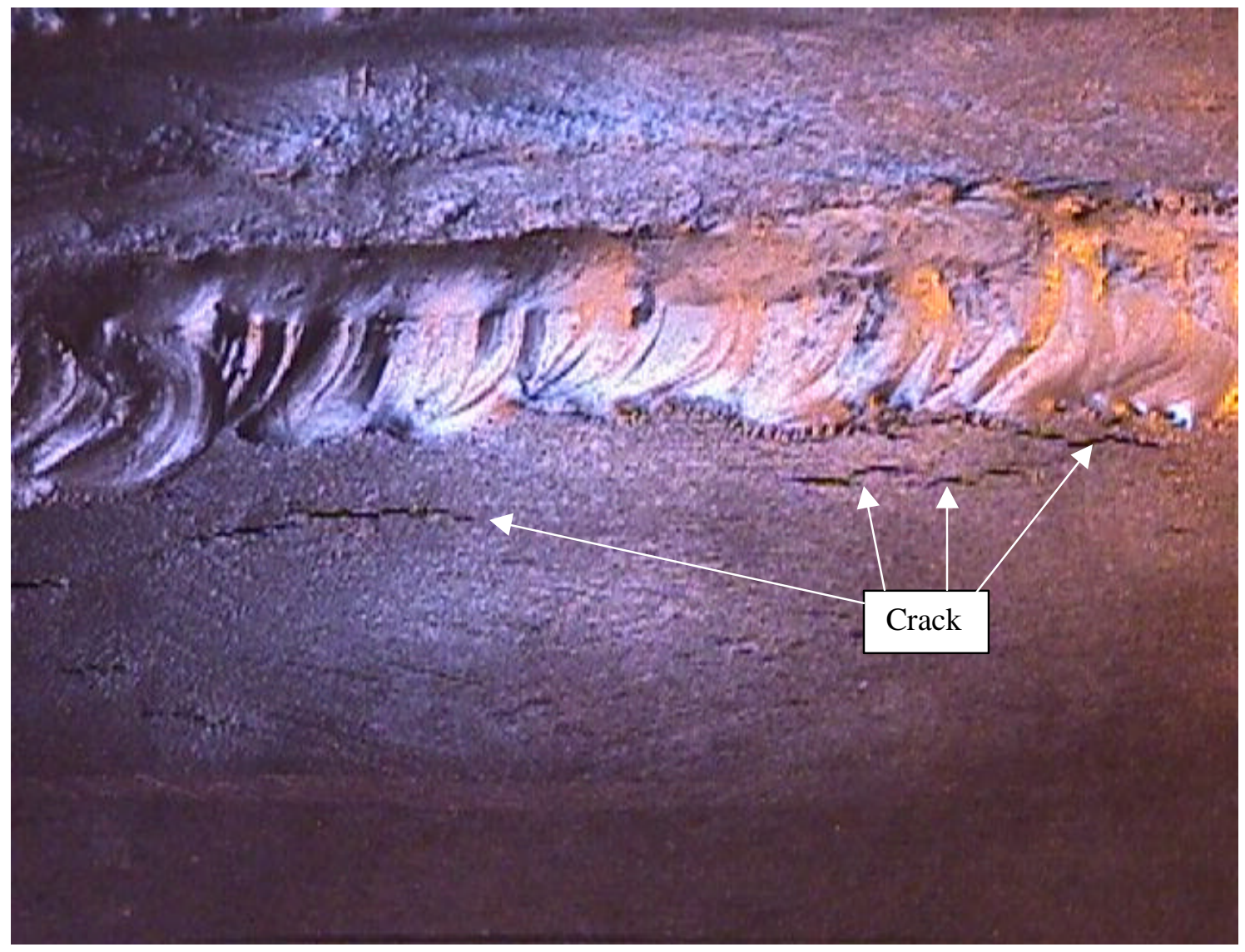

Fig. 2. Cracks found near weld at bottom of vessel. 


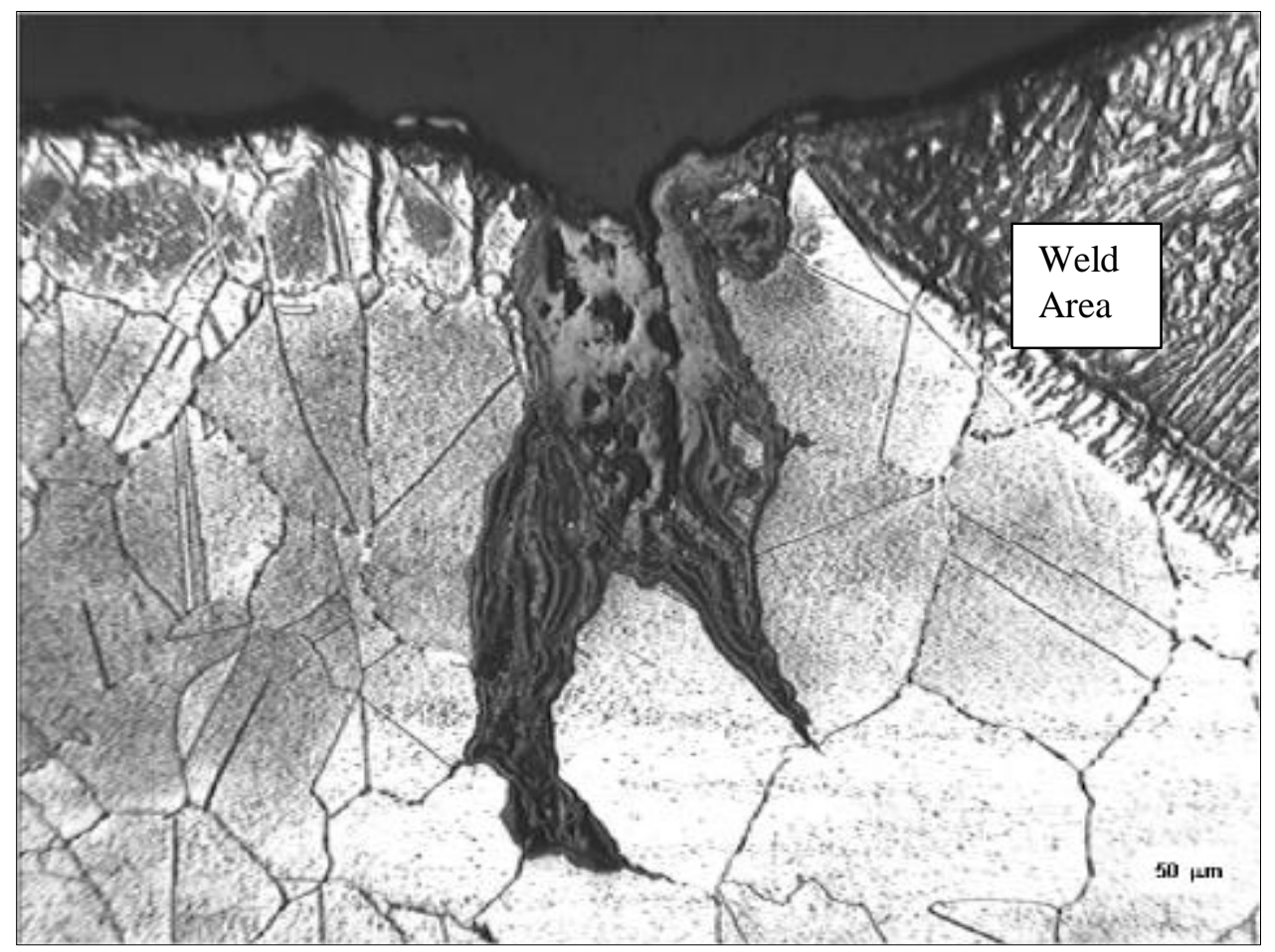

Fig. 3. Cross section of cracked region of Vessel No. 6. Weld area in top right corner.

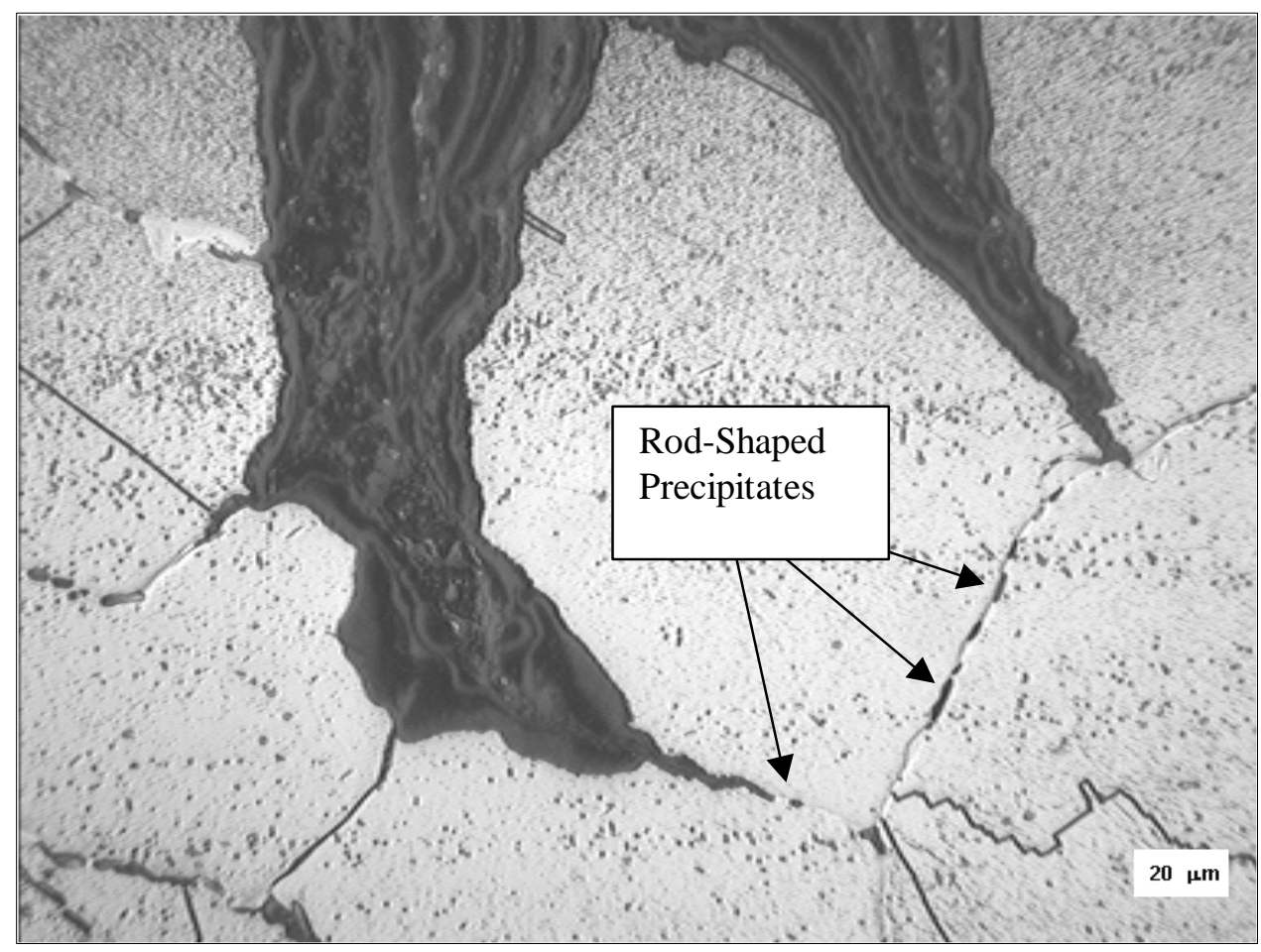

Fig. 4. Tip of crack shown in Fig. 3. Note crack propagation along grain boundary and what appear to be rod-shaped precipitates along grain boundary. 


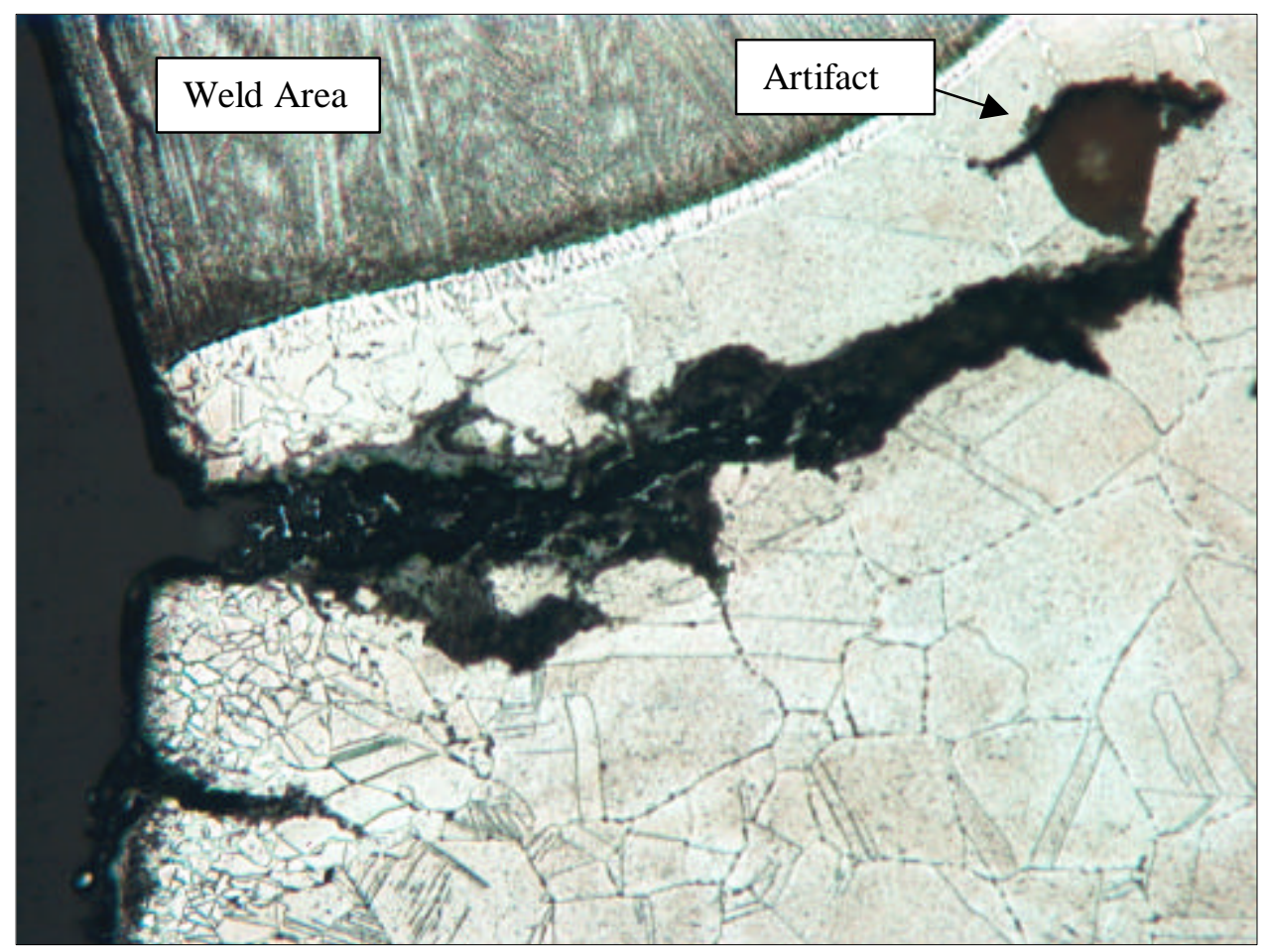

Fig. 5. Cracked region of Vessel No. 7. Weld region located along top left portion.

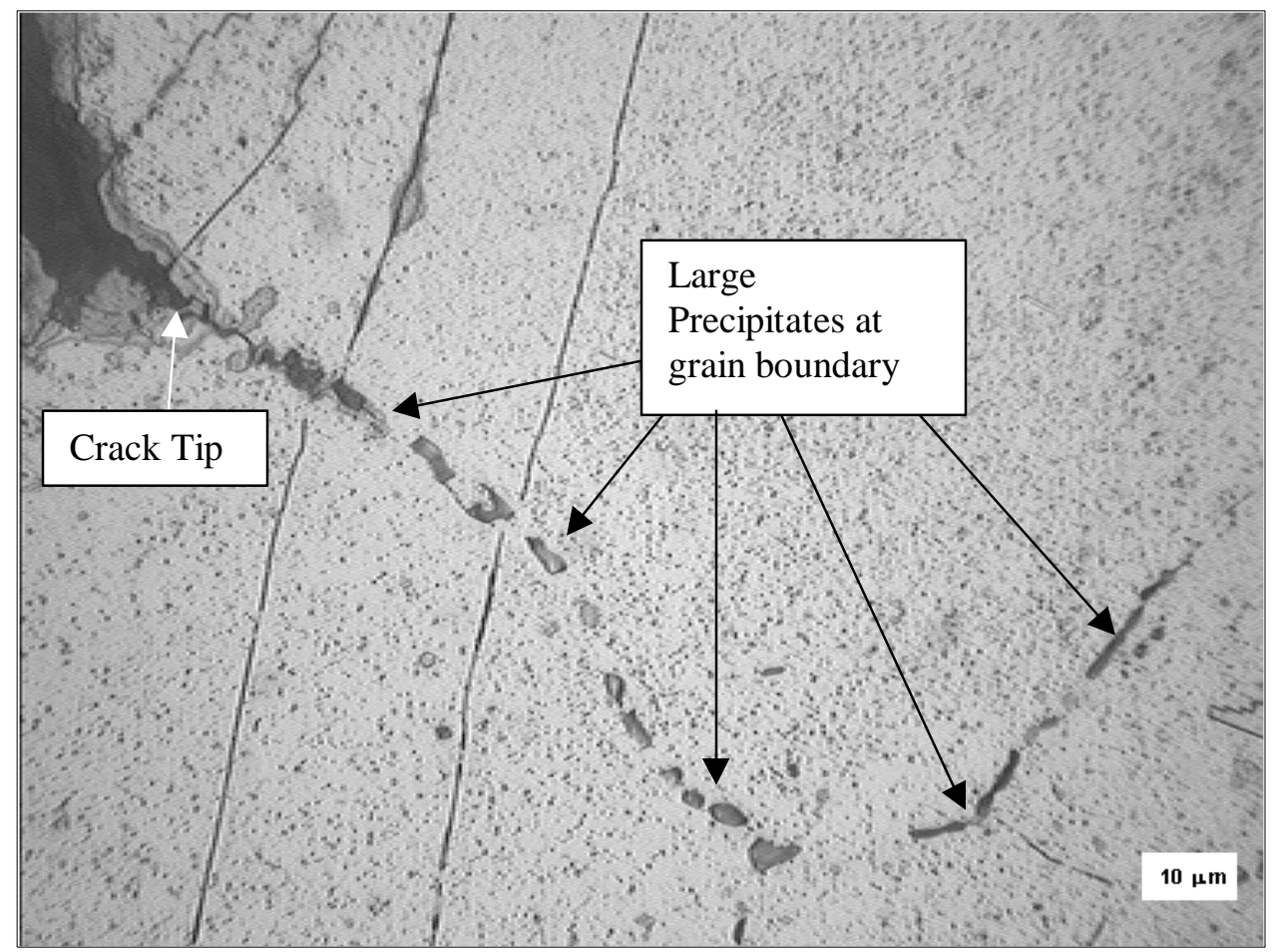

Fig. 6. Tip of crack shown in Fig. 5. Note formation of large precipitates along grain boundary and direction of crack propagation. 
Table 2. Chemical requirements and results (wt \%) of vessel materials

\begin{tabular}{|c|c|c|c|c|c|c|c|c|}
\hline $\begin{array}{l}\text { Specification or sample } \\
\text { identification }\end{array}$ & $\mathbf{C}^{a}$ & $\mathbf{S}^{a}$ & $\mathrm{Cr}^{b}$ & $\mathrm{Ni}^{b}$ & $\mathbf{S i}^{b}$ & $\mathbf{M n}^{b}$ & $\mathrm{Fe}^{b}$ & $\mathrm{Co}^{b}$ \\
\hline $\begin{array}{l}\text { ASTM specifications for Type } 309 \mathrm{~S} \\
\text { stainless steel }\end{array}$ & 0.08 & 0.030 & $22-24$ & $12-15$ & 0.75 & 2.0 & Base & 0 \\
\hline Inconel 617 (nominal composition) & 0.07 & 0.008 & 22 & 52 & 0.5 & 0.5 & 1.5 & 12.5 \\
\hline Current Vessel No. 7 Shell & 0.06 & 0.003 & 23 & 14.6 & NT & 1.9 & 59.4 & NT \\
\hline Current Vessel No. 7 Weld & $\mathrm{NT}^{c}$ & NT & 20.6 & 47.8 & NT & NT & 16.2 & 8.2 \\
\hline Nooter Vessel No. 168 Head & 0.25 & 0.017 & 23.9 & 13.1 & 0.41 & 1.2 & 61.4 & 0 \\
\hline Nooter Vessel No. 168 Weld & 0.17 & 0.017 & 23.7 & 13.1 & 0.40 & 1.4 & 61.34 & 0 \\
\hline Vessel No. 168 Head (2 ${ }^{\text {nd }}$ Analysis) & 0.18 & 0.014 & NT & NT & NT & NT & NT & NT \\
\hline Vessel No. 168 Weld ( $2^{\text {nd }}$ Analysis) & 0.06 & 0.015 & NT & NT & NT & NT & NT & NT \\
\hline Nooter Vessel No. 168 Shell & 0.13 & 0.021 & NT & NT & NT & NT & NT & NT \\
\hline Nooter No. 1134-170 Shell & 0.06 & 0.021 & 24 & 13.2 & 0.51 & 0.84 & 61.5 & NT \\
\hline Nooter No. 1134-170 Shell & 0.06 & 0.021 & NT & NT & NT & NT & NT & NT \\
\hline Nooter No. 1134-170 Weld & 0.06 & 0.018 & 26.3 & 12.5 & 1.2 & 2.2 & 57.9 & NT \\
\hline Nooter No. 1134-171 Shell & 0.06 & 0.014 & 25.4 & 12.6 & 0.74 & 1.42 & 58.9 & NT \\
\hline Nooter No. 1134-171 Weld & 0.06 & 0.013 & 26.5 & 13.0 & 1.1 & 1.87 & 57.6 & NT \\
\hline Nooter No. 1134-174 Shell & 0.05 & 0.020 & 23.8 & 13.1 & 0.70 & 0.87 & 61.6 & NT \\
\hline Nooter No. 1134-174 Weld & 0.06 & 0.017 & 25.6 & 13.3 & 1.43 & 2.44 & 57.3 & NT \\
\hline Nooter No. 1134-172 Shell & 0.05 & 0.018 & 23.6 & 13.6 & 0.81 & 1.31 & 60.7 & NT \\
\hline Nooter No. 1134-172 Weld & 0.06 & 0.016 & 26.0 & 12.8 & 1.42 & 1.66 & 58.1 & NT \\
\hline Nooter No. 1134-175 Shell & 0.06 & 0.018 & 23.6 & 13.3 & 0.62 & 1.47 & 61.1 & NT \\
\hline Nooter No. 1134-175 Weld & 0.07 & 0.016 & 27.3 & 12.3 & 0.71 & 1.88 & 57.9 & NT \\
\hline
\end{tabular}

After metallographic evaluation was completed, two of the same specimens from Vessel No. 7 were taken to the Plant Laboratory for SEM evaluation. Backscattered electron images (BEIs) of the material within the crack, shown in Fig. 7, indicate the presence of at least three different phases. EDX analysis of the material surrounding the crack was performed to identify the heavier, metallic elements, keeping in mind that elements in the periodic table below sodium are not detected by this technique. Figure 8 shows the results of the EDX analysis of the material within the crack. A white or bright field indicates the presence of the element. Nickel is shown in the top right, iron is shown in the bottom left, and chromium is shown in the bottom right. Seen in the microstructure in Fig. 9, the grain boundary precipitates near the crack shown were determined by EDX to be chromium rich.

The same sample was examined in the electron microprobe to determine the presence of the lighter elements $\mathrm{C}, \mathrm{O}, \mathrm{N}, \mathrm{Cl}$, and $\mathrm{F}$. Neither $\mathrm{Cl}, \mathrm{F}$, nor $\mathrm{N}$ was detected at any of the locations analyzed. Oxygen was detected in both the surface scale and material within the crack. Carbon was detected in the grain boundary precipitates. 


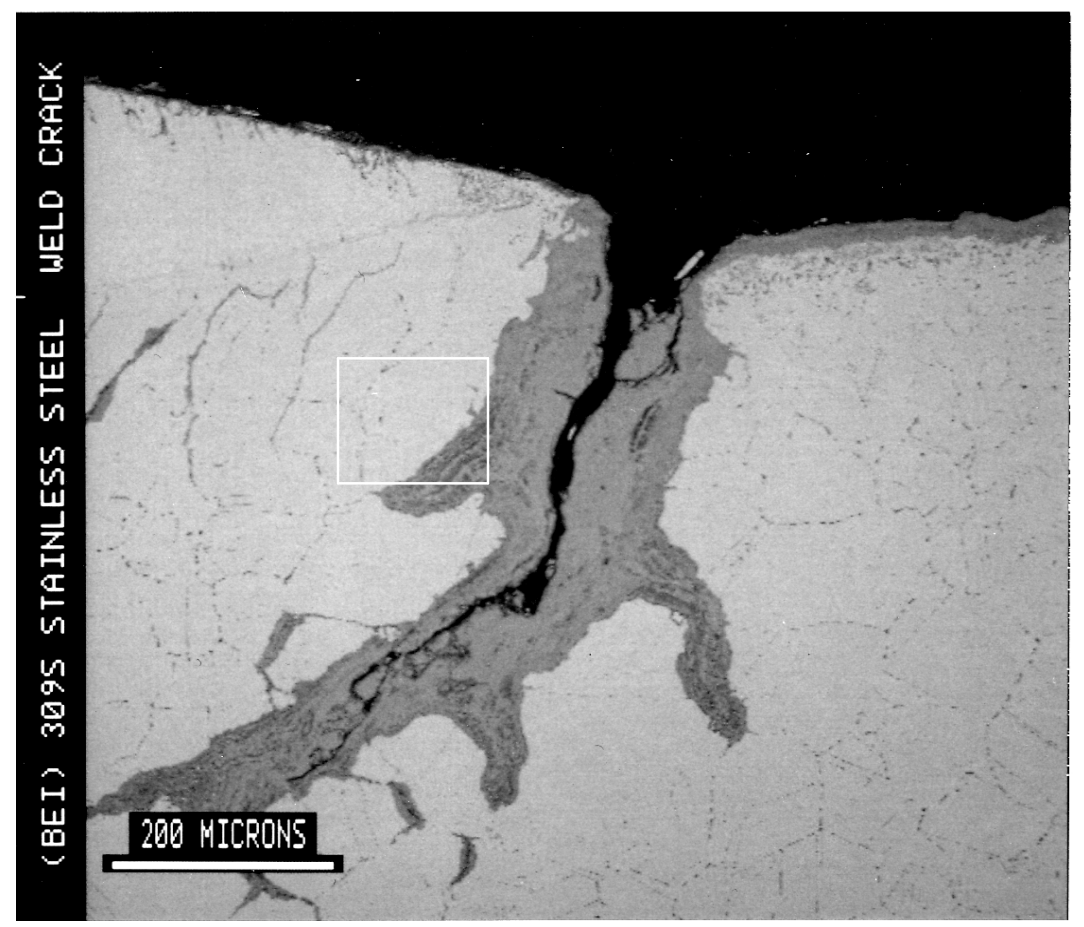

Fig. 7. BEI of material (dark gray) surrounding crack; enclosed region of crack material was analyzed to determine chemistry. 

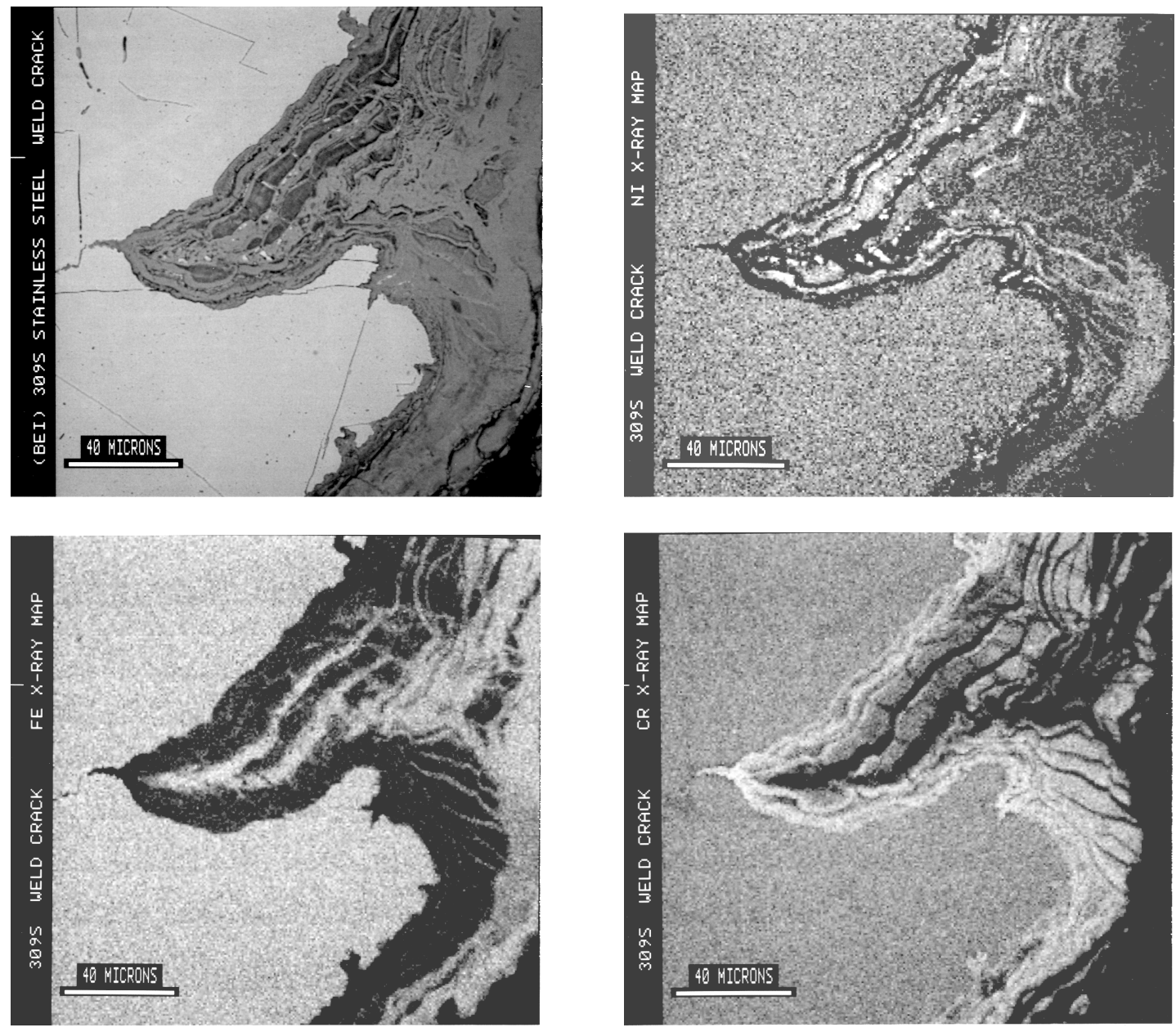

Fig. 8. EDX analysis of material in crack: $\mathrm{Ni}, \mathrm{Fe}$, and $\mathrm{Cr}$.
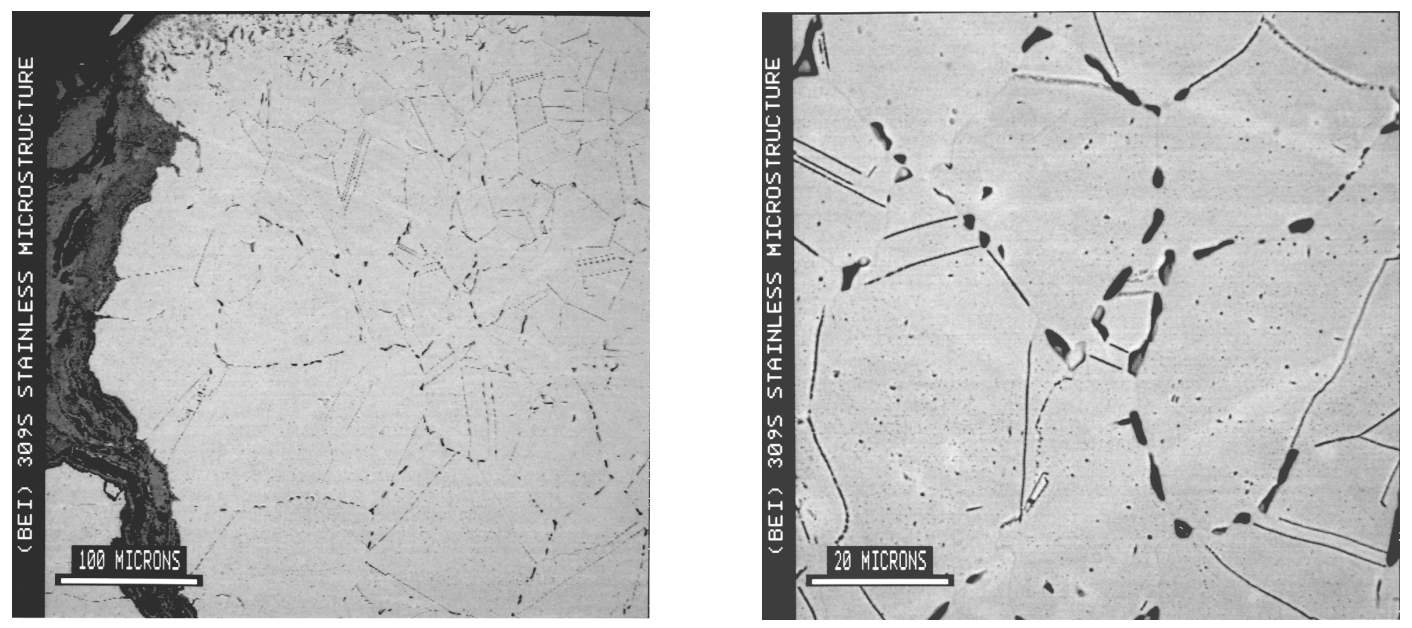

Fig. 9. Section near the crack showing precipitates rich in chromium-carbon in the Type 309S stainless steel base metal. 


\section{DISCUSSION OF RESULTS}

The base material appears to be slightly sensitized with the presence of chromium-rich carbides, and cracking appears to follow some of these grain boundaries where rod-shaped carbides are aligned. Oxide is present along the surface and within the crack opening, especially in the larger, wider cracks. Traditionally, in those cases in which sensitization is the primary cause of failure, chromium-depleted zones typically appear along the grain boundaries, cracking is branch-like, and a corrosive element is present. That is not the case here, at least not in the classical sense. The effects of having slightly sensitized material and the absence of corrosive attack, other than the presence of general oxide, do not appear substantial enough to be deemed the primary causes of cracking. Although those conditions may have contributed to crack nucleation and/or crack propagation, the primary cause of cracking appears to have been caused by highly localized, cyclic stresses in the base material adjacent to the weld. Upon examination of the coefficient of thermal expansion (CTE) properties, the filler metal (Inconel 617) is $6.4 \times 10^{-6} \mathrm{in} . / \mathrm{in} . /^{\circ} \mathrm{F}$ and the base material (Type $309 \mathrm{~S}$ stainless steel) is $8.3 \times$ $10^{-6} \mathrm{in} . / \mathrm{in} . /^{\circ} \mathrm{F}$ from room temperature to $200^{\circ} \mathrm{F}$. That is a difference in CTE of almost $2 \times 10^{-6}$ in./in. $/{ }^{\circ} \mathrm{F}$ between the two metals. In fact, for the temperature range to $1200^{\circ} \mathrm{F}$, the difference in CTE is $2400 \times 10^{-6} \mathrm{in} . / \mathrm{in}$., and the weld area is $\sim 1.5 \mathrm{in}$. wide in the affected outer surface area of the vessel. Engineering personnel, using linear elastic analysis of the stresses at the weld interface, calculated a maximum stress of 83,000 pounds per square inch (psi), which exceeds the tensile and yield strength of the stainless steel shell.

During the investigation of these cracked vessels, it was reported that vessels of a different design had performed satisfactorily in the past for this same application. Those vessels, which were manufactured by the Nooter Corporation, had curved bottoms, and the filler weld metal was believed to be Type 309S stainless steel. According to some of the old records, the material was solution annealed and quenched, which is a standard practice used throughout industry to minimize sensitization in stainless steels. A section of one of the older curved-bottom vessels (No. 168) was analyzed to determine if the filler and base metals were indeed Type $309 \mathrm{~S}$ stainless steel. However, the carbon results, as Table 2 illustrates, were found to be higher than the $0.08 \mathrm{wt} \%$ maximum specified for Type 309S stainless steel. Yet, the vessel apparently showed no evidence of cracking. Since it appears that cracking observed in the current vessels may be associated with some type of creep fatigue mechanism, the role of carbon in the alloy for prolonged periods of time at elevated temperatures becomes an important factor. Reduced carbon in solution in the low-carbon (Type 304L and 316L stainless steel) and stabilized grades (Type 321 and 347 stainless steel) results in reduced creep strength and creep-rupture strength. ${ }^{2}$ As the hold time at elevated temperature is increased, the effect of rupture ductility becomes more pronounced. The lower the rupture ductility, the lower the creep-fatigue endurance for low-carbon stainless steels. The higher the carbon content, the higher the creep-fatigue strength - but with the higher carbon, the greater the chance of sensitization becoming a problem at these operating conditions. In addition, ASME Boiler and Pressure Vessel (B\&PV) code footnotes require the carbon content for Type 309S stainless steel to be 0.04 wt \% minimum and 0.08 wt $\%$ maximum for use at these temperatures. Consequently, a decision was made not to use the vessel with the higher carbon content.

Another section of a curved-bottom vessel (No. 1134-170) was examined for cracks and microstructure, and a chemical analysis was performed to verify the filler metal. There were no cracks; the microstructure, shown in Fig. 10, looked normal; and both the filler metal and base metal were identified as Type 309S stainless steel. In fact, the microstructure showed very little evidence of sensitization. This was rather surprising too because most material handbooks indicate that austenitic 
stainless steels, such as Type 309S stainless steel, become susceptible to intergranular corrosion when subjected to temperatures in the range of 480 to $815^{\circ} \mathrm{C}\left(900\right.$ to $\left.1500^{\circ} \mathrm{F}\right)$, generally from welding or prolonged service conditions. ${ }^{3}$

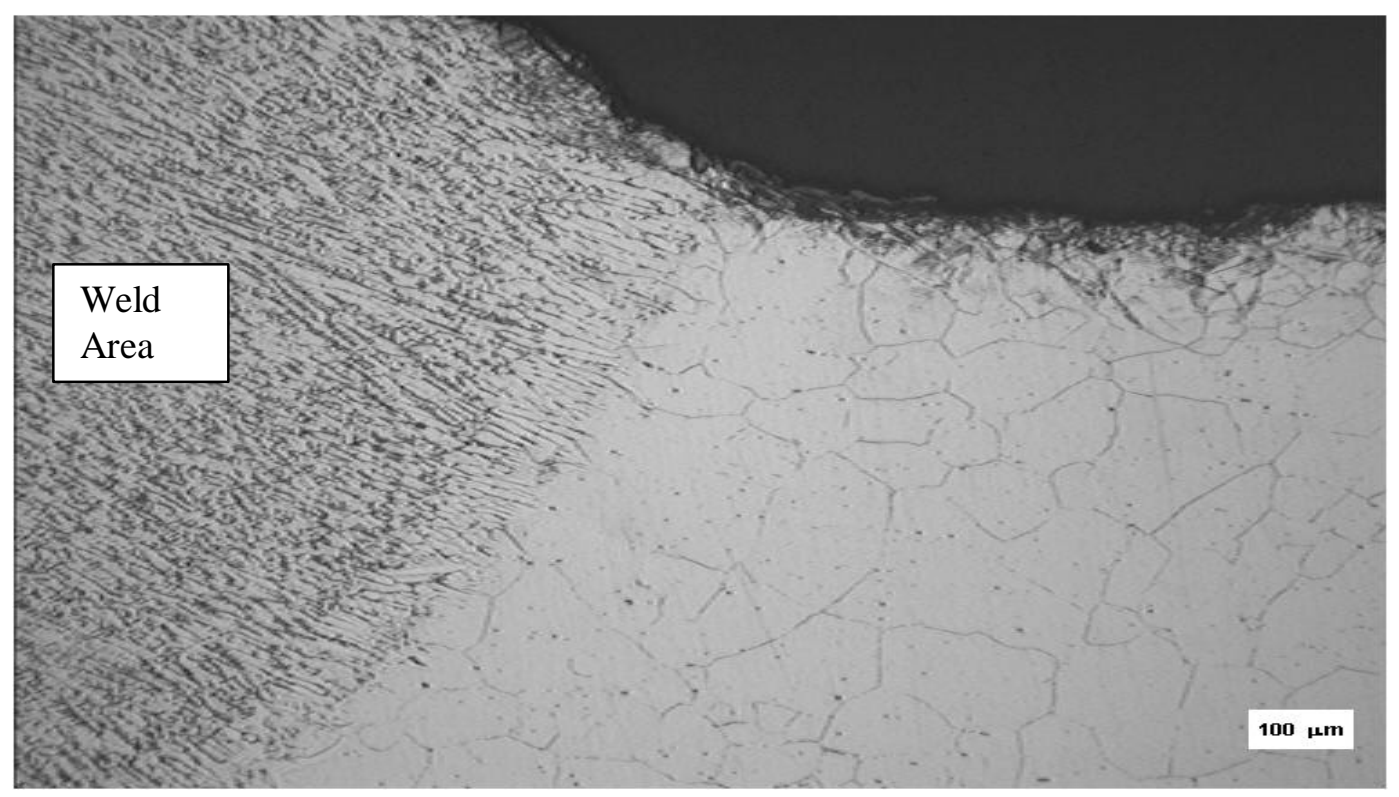

Fig. 10. Welded region of Vessel No. 170 is crack-free and shows very little evidence of sensitization.

Another concern with long-term exposure in the range of 1050 to $1800^{\circ} \mathrm{F}$ is the formation of sigma phases, yet neither condition was prevalent in the older Nooter vessels. Even though stabilized stainless steels are often recommended for service in these temperature ranges, ${ }^{4}$ the experience of having operated the older vessels for years with very little evidence of degradation indicates that the design and material selection for the Nooter vessels were satisfactory. With this in mind, a short-term solution was initiated to repair the vessels and keep operations going by combining sections of the curved-bottom vessels with noncracked sections of the current vessel.

One of the few differences in the process equipment between the current process and the "old" process is that forced-air cooling was added to the current process to reduce cycle time and increase production rate. Forced air may actually increase strain in the welded region and add to the stress magnitude. The bottom of the vessel was changed from a curved bottom to a flat bottom to accommodate a height restriction and a process problem in the new furnace and processing area.

\section{CONCLUSIONS}

The primary cause of cracking was determined to be high stresses induced at the weld interface during thermal cycling of the vessel (creep-fatigue interaction). The high stresses resulted from the mismatch among the CTEs of the filler metal (nickel-based Inconel 617) and the shell (Type 309S stainless steel) and the joint design. Stresses were imposed during prolonged heating at service temperatures (expanding) and forced-air cooling (contracting) of the vessel during each cycle of 
operation. Even though the stainless steel shell exhibited some evidence of sensitization, the effect of sensitization on cracking was determined to play a minor role, perhaps providing a less resistant path for slow crack propagation. The recommendation to change the alloy to a stabilized stainless steel is difficult to justify because of the excellent results observed in the older curved-bottomed Type 309S stainless steel vessels that had matching Type 309S stainless steel filler metal. In light of the results of this investigation, the authors recommend that the nickel-based filler metal be eliminated and that new or repaired vessels specify stainless steel filler metal that is compatible with the Type 309S stainless steel shell. Filler metal Type $309 \mathrm{H}$ stainless steel, which has a minimum carbon specification of $0.04 \mathrm{wt} \%$, may be considered, provided the carbon content meets the specification of 0.08 wt $\%$ maximum. The flat-bottom design should be replaced with a curved-bottom design to help reduce stresses. Finally, it may be advisable to eliminate forced-air cooling or at least to evaluate the vessel temperature at which forced-air cooling would not contribute to excessive stresses in that region.

\section{ACKNOWLEDGMENTS}

The authors would like to thank the following for their support, input, and discussions: W. D. Shipley, Jr.; R. Summers; R. M. Jessee; D. J. Etzler; D. D. Bunton; D. B. Rainey; J. C. Walls; K. H. Luk; B. W. Riemer; T. L. Ryan; D. Benjamin; L. Y. Sunwoo; L. A. Headrick; S. J. Pawel; R. L. Bridges; L. T. Ratcliff; W. L. Bolinger; and D. T. Keebler.

\section{REFERENCES}

1. F. Hipshire, "Comments-AVS Repair Procedures-HRV's 9-17-92 LPR Settler/Hydriders Furnaces, P.O. 93Y-AJC15V, S-08531-21, WBS 1.1.4.2," personal communication to R. B. Shnider, Martin Marietta Energy Systems, Inc., November 2, 1992.

2. Metals Handbook, Vol. 10, eighth ed., pp. 177-179, American Society for Metals, Metals Park, Ohio, 1975.

3. Metals Handbook, Vol. 1, 10th ed., pp. 706-711, ASM International, Materials Park, Ohio, 1990.

4. Metals Handbook, Vol. 1, 10th ed., pp. 934-935, ASM International, Materials Park, Ohio, 1990. 


\section{Distribution}

Oak Ridge National Laboratory
S. J. Pawel
L. Y. Sunwoo
Oak Ridge Y-12 Plant
J. C. Anderson
E. L. Bird
W. L. Bolinger
D. D. Bunton
C. C. Edwards
D. J. Etzler
J. L. Frazier
C. R. Hammond
L. A. Headrick
R. M. Jessee
B. D. Johnston
K. H. Luk
W. A. Muenzer
T. M. Mustaleski, Jr.
W. G. Northcutt, Jr.
B. J. Owens
P. A. Porter
D. B. Rainey
T. L. Ryan
R. S. Sampson (7)
W. D. Shipley, Jr.
J. C. Walls
OSTI (2)
Y-12 Central Files
9202 File Point 